\title{
Measuring Efficiency in Higher Education in Korea
}

\author{
GwangHo Han ${ }^{1}$ and HyunWook Ryu ${ }^{2}$ \\ ${ }^{1}$ Ph.D. in Real Estate, Konkuk University, Seoul, Korea \\ ${ }^{2}$ Associate Professor, Department of Global Trade and Management, Shinhan \\ University, Gyeonggi-do, Korea \\ ${ }^{1}$ realestatepro@konkuk.ac.kr, ${ }^{2}$ ryuhw@shinhan.ac.kr
}

\begin{abstract}
The purpose of this study is to empirically investigate efficiencies of private institutions of higher education in Korea. The analysis is conducted with DEA (Data Envelopment Analysis) and Fama-Macbeth regression for the efficiency growth estimations. The efficiency score indicates if an institution has capacity for improvement, and we aimed to distinguish the institution samples during a specific period of time, thus the national higher education assessment provides a useful tool in evaluating the performance of the institutions. The DEA results strongly support the hypothesis that the assessment has a positive effect on conventional academic outputs such as research published and the number of student enrolled. Hence, private institutions have incentives to relay more input variables to the output. Our findings satisfy the CCR as well as BCC. Considering the ratio of total scores and the difference in scores among the institutions, grade C-group (the subgroup) shows statistically significant in efficiency improvement between the year 2010 and 2015. To sum up the result, the first assessment cycle had a positive effect on improving the overall efficiency of Korean institutions in higher education, and specifically, the improved effect can be interpreted as strong in subgroup. To discuss the endogeity, a regression method has applied for examining gradegroup and efficiency growth. The findings reveal that the recent appearance of assessments of higher education institutions poses the question of the consistency of efficiency scores derived from different grades of group.
\end{abstract}

Keywords: DEA, Fama-Macbeth regression, Higher education, Efficiency

\section{Introduction}

The concept of 'restructuring' has been foreign in Korean history of higher education. The instance inceptively occurred in 1977 when two-year college system was introduced. All of the existing junior colleges and vocational high schools were unified into two-year college, and four-year higher education institutions began to increase the number of entrance quota. In the 1990s, Baby-boomers became older, and 3rd industrial revolution asked for the jobs with university-diploma. Both triggered the demand for university degrees, which intensified educational zeal. As the government adopted a policy of lowering standards for establishing universities, the number of higher education institutions increased sharply; the policy enacted in 1995 brought 20 universities in 1996 and total of 60 added over 17 years.

The first course of action took place with the 'National University Restructuring Plan' in 1998, after the Asian financial crisis. Due to the changed population structure with a low

Article history:

Received (December 21, 2020), Review Result (January 23, 2021), Accepted (February 26, 2021) 
birthrate and an aging society, the Ministry of Education (MOE) announced its 'University Structural Reform Plan' (the 'Plan') in late 2013; it estimated the total enrollment quota of higher education institutions over the number of high school graduates by 2018 . The aim of the Plan was to reduce the enrollment quota of less-competitive institutions through assessment, which the government took the de facto control. The Plan was based on a three-year cycle, and this first cycle ended in 2015; the 2nd cycle closed in 2018 and the 3rd one is up ahead in 2021.

Restructuring of higher education was global trend in the 1990s, core of which was to redefine the relationship between the institutions and social demands. The trend was accompanied by diversification in academic operations such as expansion of academic fields (departments) and/or life-long education. In the same vein, results of the Plan (the restructuring assessment) sparked a wave of reform attempts in such areas as faculty's securement rate, academic supports, the number of scholarships awarded, etc. [10].

The purpose of this study is to provide empirical evidence on efficiency in higher education in Korea by analyzing private universities. We examine the hypothesis about the efficiency in that the assessment policy of Korean government add value by re-uniting broken competencies. We investigate from conservative perspective such that the efficiency outcome is set to be research publications and student enrolment. As various functions have expanded during the years, it has become harder to coordinate and focus on core academic competences. This study aims to find whether the assessment causes private institutions improve academic outcome(s).

To understand the importance of efficiency in different grade groups of institutions in explaining efficiency scores and growth status, we perform the analysis in two phases. In the first phase, the analysis includes DEA analysis by comparing the mean of efficiency and inefficiency scores by year; CCR (Constant Return to Scale) and BCC (Variable Return to Scale). In the second phase of the analysis, we consider various grade-groups and efficiency growth as dependent variable in the models.

\section{Literature review}

Many studies have shed lights on efficiency of the institutions in higher education by utilizing DEA [3][6]. The method is to find how technical efficiency is achieved, and most researches use human resources such as the staff (academic and/or non-academic), financial and material factors as input proxies. No previous literature uses non-consumable resource. The outputs vary from studies on which the researcher(s) highlight. No negative outputs are chosen in previous studies.

Table 1. Input and output factor used in previous research for the DEA analysis

\begin{tabular}{|c|c|c|}
\hline Author & Input/Output & Variables \\
\hline \multirow{2}{*}{$\begin{array}{l}\text { Leitner, Prikoszovits, } \\
\text { Schaffhauser-Linzatti, } \\
\text { Stowasser, and } \\
\text { Wagner(2007) [7] }\end{array}$} & Input & $\begin{array}{c}\text { - Number of staff } \\
\text { - Number of room space }\end{array}$ \\
\hline & Output & $\begin{array}{c}\text { - Number of patents } \\
\text { - Number of publications }\end{array}$ \\
\hline $\begin{array}{l}\text { Katharaki and Katharakis } \\
\text { (2010) [4] }\end{array}$ & Input & $\begin{array}{c}\text { - Number of non-academic and academic staff } \\
\text { - Number of enrolled students } \\
\text { - operational expenses }\end{array}$ \\
\hline
\end{tabular}




\begin{tabular}{|c|c|c|}
\hline & Output & $\begin{array}{l}\text { - Number of graduates } \\
\text { - Income from research }\end{array}$ \\
\hline \multirow{2}{*}{ Daghbashvan (2013) [1] } & Input & $\begin{array}{l}\text { - Number of professors } \\
\text { - Number of Ph.D student } \\
\text { - Number of research staff } \\
\text { - Number of technical-administrative staff }\end{array}$ \\
\hline & Output & $\begin{array}{l}\text { - Number of authored books } \\
\text { - Number of review papers } \\
\text { - Number of conference papers } \\
\text { - Number of journal papers }\end{array}$ \\
\hline \multirow{2}{*}{$\begin{array}{c}\text { Kipesha and Msigwa (2013) } \\
\text { [5] }\end{array}$} & Input & $\begin{array}{l}\text { - Number of enrollment students } \\
\text { - Total number of academic and non-academic } \\
\text { staff } \\
\text { - Number of staff }\end{array}$ \\
\hline & Output & $\begin{array}{l}\text { - Number of graduates in undergraduate } \\
\text { - postgraduate levels } \\
\text { - Number of graduates }\end{array}$ \\
\hline \multirow[b]{2}{*}{$\begin{array}{l}\text { Martinez-Campillo and } \\
\text { Fernandez-Santos (2020) [9] }\end{array}$} & Input & - Number of enrollment students \\
\hline & Output & $\begin{array}{l}\text { - Number of graduates } \\
\text { - Number of scientific articles published in the ISI } \\
\text { web of science, }\end{array}$ \\
\hline \multirow{2}{*}{$\begin{array}{c}\text { Mammadov and Aypay } \\
\text { (2020) [8] }\end{array}$} & Input & $\begin{array}{l}\text { - Faculty member/number of programs } \\
\text { - Number of scientific research projects/Number } \\
\text { of programs }\end{array}$ \\
\hline & Output & $\begin{array}{l}\text { - Citation/publications } \\
\text { - Research project revenue share / budget } \\
\text { allowance } \\
\text { - Number of PhD graduates / Number of doctoral } \\
\text { programs }\end{array}$ \\
\hline
\end{tabular}

\section{Empirical result}

\subsection{Sample}

The data were obtained from the database of Higher Education in Korea, operated by the Korean Council for University Education according to relevant law. As existed a great number of input and output variables in higher education environment, we reduce the factors at the conservative perspective. The institutions' physical condition, faculty caliber and research capability are injected as inputs, and research outcomes and enrolment rate are applied as output variables.

\subsection{T-test}

[Table 2] demonstrates the efficiency average of the annual and scale calculated using the CCR models (under the assumption of 'Constant Return to Scale) and BCC (under the assumption of 'Variable Return to Scale). From the year 2010 to 2015, the efficiency of private institutions in Korea has improved, and these results can be inferred that the government's 
assessment could be contributed to increasing efficiency overall. T-test result in [Table 3] is conducted to identify the efficiency between 2010 and 2015. The result confirms statistically significant mean difference of efficiency scores in both CCR and BCC.

Table 2 Mean of Efficiency Score and the Inefficiency score by year

\begin{tabular}{|c|c|c|}
\hline Year & CCR & BCC \\
\hline 2010 & 0.517 & 0.652 \\
\hline 2011 & 0.533 & 0.661 \\
\hline 2012 & 0.593 & 0.679 \\
\hline 2013 & 0.600 & 0.700 \\
\hline 2014 & 0.609 & 0.683 \\
\hline 2015 & 0.635 & 0.726 \\
\hline 2016 & 0.623 & 0.688 \\
\hline 2017 & 0.654 & 0.721 \\
\hline 2018 & 0.583 & 0.665 \\
\hline 2019 & 0.600 & 0.688 \\
\hline
\end{tabular}

Table 3 Mean difference test of all sample: 2010 and 2015

\begin{tabular}{|c|c|c|c|c|}
\hline Variable & 2010 Mean & 2015 Mean & Difference & P-value \\
\hline CCR & 0.5167 & 0.6352 & -0.1184 & 0.000 \\
\hline BCC & 0.6518 & 0.7264 & -0.0747 & 0.002 \\
\hline
\end{tabular}

\subsection{Regression result}

For the robustness of the analysis results that showed greater improvement in efficiency at lower-graded institutions in the assessment, the following regression model was set with the growth rate of efficiency set as dependent variable, the function of which is presented as follows.

Efficiency Growth $=\alpha_{0}+\beta_{1}$ Grade $+\beta_{2}$ Region $+\beta_{3}$ Age $+\beta_{4}$ Transfer Income $+\epsilon$ (1)

Since the data in this study are unbalanced panel data, we use Fama-Macbeth Resistance [2] control endogenesis. Independent variables utilize dummy variables coded by University Evaluation Grade A, Grade B and C, and Grade under C to test the main assumptions of this study. Use Region, Age, and Transfer Income as control variables. Region is to control differences in university position. Age is included as control variable over the period, and Transfer Income as a proxy representing institutions' management competences. 
Table 4. Mean difference test of under-C grade universities: 2010 and 2015

\begin{tabular}{|c|c|c|}
\hline \multirow{2}{*}{ Variables } & CCR growth & BCC growth \\
\hline & (1) & (2) \\
\hline \multirow{2}{*}{ Grade: B and C } & $-0.084 *$ & $-0.071^{*}$ \\
\hline & {$[-1.901]$} & {$[-1.865]$} \\
\hline \multirow{2}{*}{ Grade: A } & $-0.077 * *$ & $-0.057 *$ \\
\hline & {$[-1.974]$} & {$[-1.855]$} \\
\hline \multirow{2}{*}{ Region } & -0.002 & -0.025 \\
\hline & {$[-0.049]$} & {$[-1.035]$} \\
\hline \multirow{2}{*}{ Age } & $-0.002 * * *$ & $-0.001 * * *$ \\
\hline & {$[-2.625]$} & {$[-2.861]$} \\
\hline \multirow{2}{*}{ Transfer Income } & $-2.38 \mathrm{E}-10^{* *}$ & $-1.786 \mathrm{E}-10$ \\
\hline & {$[-2.070]$} & {$[-0.404]$} \\
\hline \multirow{2}{*}{ Constant } & $0.202 * * *$ & $0.159 * * *$ \\
\hline & [3.191] & {$[2.848]$} \\
\hline Observations & 1,016 & 1,014 \\
\hline R-Square & 0.031 & 0.033 \\
\hline
\end{tabular}

Fama-MacBeth method [2] is modified for panel data sets, and the test result is shown in [Table 4]. The coefficients for the efficiency improvement of $\mathrm{C}$-grade institutions are statistically significant that is higher than that of A-grade institutions. The estimator is consistent with the results of the T-test, and attests to our hypothesis that the policy effect of the assessment would have been greater in the lower-graded institutions.

\section{Conclusions}

The study of efficiency is meaningful in identifying sources of inefficiencies to help the management initiate reforms and/or take relevant measures in higher education. To test the efficiency of universities in Korea, we conduct two analysis. The first analysis is conducted to compare mean efficiencies among different institutions overall efficiency over time. The second analysis covers the effect of policy measure with its contribution to the institutions' operation in efficient manner. The empirical findings of this study reveal that the overall efficiency for private institutions has improved overtime, and the efficiency improvement was greater than other period of time investigated. The result indicates the role of government's assessment policy at specific period of time in higher education sector. 
Although the result of this empirical application provides useful and interesting outcomes, further step would be helpful to find whether the assessment policy makes institutions meet the needs of academic objectives.

\section{References}

[1] Z. Daghbashyan, "Do university units differ in the efficiency of resource utilization? A case study of the royal institute of technology (KTH), Stockholm," Journal of Applied Research in Higher Education, (2013)

[2] E. F. Fama and James D. MacBeth, "Risk, return, and equilibrium: Empirical tests," Journal of political economy, vol.81, no.3, pp.607-636, (1973) DOI: 10.1086/260061

[3] C. Kao and Hsi-Tai Hung, "Efficiency analysis of university departments: An empirical study," Omega, vol.36, no.4, pp.653-664, (2008) DOI: 10.1016/j.omega.2006.02.003

[4] M. Katharaki and George Katharakis, "A comparative assessment of Greek universities' efficiency using quantitative analysis," International journal of educational research, vol.49, no.4-5, pp.115-128, (2010) DOI: 10.1016/j.ijer.2010.11.001

[5] E. F. Kipesha and Robert Msigwa, "Efficiency of higher learning institutions: Evidences from public universities in Tanzania," Journal of Education and practice, vol.4, no.7, pp.63-73, (2013)

[6] E. E. Lehmann, M. Michele, S. Paleari, and S. A. E. Stockinger, "Approaching effects of the economic crisis on university efficiency: A comparative study of Germany and Italy", Eurasian Business Review, vol.8, no.1, pp.37-54, (2018) DOI: 10.1007/s40821-017-0091-7

[7] K. Leitner, J. Prikoszovits, M. Schaffhauser-Linzatti, R. Stowasser, and K. Wagner, "The impact of size and specialization on universities' department performance: A DEA analysis applied to Austrian universities," Higher education, vol.53, no.4, pp.517-538, (2007) DOI: 10.1007/s10734-006-0002-9

[8] R. Mammadov and Ahmet Aypay, "Efficiency analysis of research universities in Turkey," International Journal of Educational evelopment, vol.75, pp.102-176, (2020) DOI: 10.1016/j.ijedudev.2020.102176

[9] A. Martínez-Campillo and Y. Fernández-Santos, "The impact of the economic crisis on the (in) efficiency of public higher education institutions in Southern Europe: The case of Spanish universities," Socioecon.Plann.Sci., vol.71, pp.100771, (2020) DOI: 10.1016/j.seps.2019.100771

[10] D. Shin and Daehun Chung, "Multi-level and multi-faceted institutional dynamics: Neoliberal reforms in Korean universities, 2008-2013,” Asia Pacific Business Review, pp.1-25, (2020) DOI: $10.1080 / 13602381.2020 .1788289$ 